\title{
FINANCING ANALYSIS OF SMALL AND MEDIUM ENTERPRISES USING MUDHÂRABAH CONTRACTS IN KOPERASI SIMPAN PINJAM AND SHARIA FINANCING BAIT AL-MÂL WA AL-TAMWîL EL-TAQWA CIAMIS
}

\author{
Fitranty Adirestuty \\ Institut Agama Islam Darussalam (IAID) Ciamis-Jawa Barat \\ Email: fitranty.adirestuti@iaid.ac.id \\ Rini Irnawati \\ Institut Agama Islam Darussalam (IAID) Ciamis-Jawa Barat \\ Yani Mulyani \\ Institut Agama Islam Darussalam (IAID) Ciamis-Jawa Barat
}

\begin{abstract}
This study aims to analyze the financing of Micro, Small, and Medium Enterprises (MSMEs) using the mudhârabah contract provided by KSPPS-BMT eL-Taqwa Cidewa Ciamis. The mudhârabah financing product KSPPS-BMT eL-Taqwa Cidewa Ciamis is a solution for interest-based banks. This descriptive-qualitative research utilizes observation, interview, and document study techniques to obtain data information. The results showed that the implementation of the mudhârabah contract at KSPPS-BMT eL-Taqwa Cidewa Ciamis in determining the profit-sharing was adjusted to the understanding and requests of prospective customers. Two categories of profit-sharing are carried out, the profit-sharing ratio (\%) for both parties is determined at the beginning of the contract before the income is known so that the monthly installment payments are fixed, and the profit-sharing ratio (\%) is determined at the beginning of the agreement. Still, the installment payments are not fixed because adjusted to customer income. As for the role of the mudhârabah contract for micro, small and medium enterprises (MSMEs), of course, there are various kinds of developments experienced by every entrepreneur, seen from the good developments and some experiencing poor development so that they encounter obstacles in their business.
\end{abstract}

\begin{abstract}
Abstrak
Penelitian ini bertujuan untuk menganalisis pembiayaan Usaha Mikro Kecil dan Menengah (UMKM) dengan menggunakan akad mudhârabah yang diberikan oleh KSPPS-BMT eL-Taqwa Cidewa Ciamis. Produk pembiayaan mudhârabah yang disediakan KSPPS-BMT eL-Taqwa Cidewa Ciamis merupakan salah satu solusi atas bank yang berbasis bunga. Penelitian deskriptif-kualitatif ini memanfaatkan teknik observasi, wawancara, dan studi dokumen untuk memperoleh informasi data. Hasil penelitian menunjukkan bahwa pelaksanaan akad mudhârabah di KSPPS-BMT eLTaqwa Cidewa Ciamis dalam penentuan bagi hasil disesuaikan dengan pemahaman serta permintaan calon nasabah. Dua kategori penentuan bagi hasil yang dilakukan yaitu nisbah (\%) bagi hasil kedua belah pihak ditentukan pada awal akad sebelum diketahui pendapatan sehingga pembayaran angsuran tiap bulan bersifat tetap dan penentuan nisbah (\%) bagi hasil ditentukan pada awal akad akan tetapi pembayaran angsuran tidak tetap karena disesuaikan dengan pendapatan nasabah. Adapun peranan akad mudhârabah bagi usaha mikro kecil dan menengah (UMKM) tentunya berbagai macam perkembangan yang dialami setiap pengusaha, dilihat dari adanya perkembangan yang baik dan ada yang mengalami perkembangan kurang baik sehingga mengalami hambatan dalam usaha.
\end{abstract}


Keywords: Bait Al-Mâl wa Al-Tamwl, Sharia Savings and Loans Cooperatives, Mudhârabah Contracts, Micro, Small and Medium Enterprises

\section{Introduction}

Financial institutions have a critical role in moving the wheels of the economy. Daily life indeed cannot be separated from worshiping Allah and conversing with fellow human beings. Worship is a vertical relationship between Allah with humans as His servants. At the same time, mu'amalah itself is a horizontal relationship between humans, including socio-economic relationships such as buying and selling trade, renting, borrowing, and so on.

Muslims are not allowed to eat usury in running the economy, both investment and trade. Today, Indonesia has many emerging Sharia-based financial institutions. One of them is Bait al-Mâl Wa al-Tamwîl or often called BMT. Bait al-Mâl Wa alTamwîl (BMT) is one of the simplest Sharia Financial Institutions. This institution does not receive any subsidy from the government. BMT operates among the lower economic community and seeks to help develop productive businesses. As a Shariah Financial Institution, BMT must adhere to Shariah principles.

BMT distributes existing funds through financing to improve the economy for Micro, Small, and Medium Enterprises based on Sharia principles. One of the common characteristics inherent in rural communities in Indonesia is weak capital. Capital is an essential element in supporting increased production and living standards of rural communities, especially for entrepreneurs or traders of weak economic groups (small businesses).

One of the financings used by Bait al-Mâl Wa al-Tamwîl is using mudhârabah financing (mudhârabah contract). Qardawi (1997: 184) says that this financing is indirectly a rejection of the interest system applied by conventional banks. The existence of this mudhârabah financing, of which helps ease the community in financing so that they can avoid usury which is clearly prohibited in the Qur'an.

Based on previous research, namely Ananda's research (2011: 67) that before and after receiving mudhârabah financing from BMT At-Taqwa Halmahera in Semarang City, there was business development for Micro, Small, and Medium Enterprises (MSMEs), namely seen from business capital, sales turnover, and profits.

Therefore, to find out the results of the analysis of the mudhârabah financing contract, this research was conducted on BMT eL-Taqwa Cidewa Ciamis because the majority of its customers are local communities and are engaged in Micro, Small, and Medium Enterprises.

\section{Theoretical review}

Savings and Loans Cooperative and Sharia Financing

According to Chaniago (1982:59) savings and loan cooperatives (credit cooperatives) are cooperatives whose members are everyone who has a direct interest in the credit field. The goals of credit cooperatives are (Chaniago, 1982:5): (1) Assisting 
the credit needs of members who are in dire need with light conditions. (2) Educate members to be active in saving regularly to form their capital. (3) Educate members to live frugally by setting aside a portion of their income. (4) Increase knowledge about cooperatives.

The Sharia Savings and Loans and Financing Cooperative (KSPPS) or previously called the Sharia Financial Services Cooperative (KJKS) was born from Bait al-Mâl Wa al-Tamwîl (BMT), is a Sharia microfinance entity that is unique and specific to Indonesia. The role of KSPPS according to Per/M.KUKM/IX/2015 article 1 in carrying out its functions and roles, cooperative KSPPS whose business activities include savings, loans, and financing according to sharia principles, including managing ZISWAF (Zakat, Infaq, Shadaqah, and Waqf) and as an institution business (tamwil).

Government regulations in implementing Savings and Loans and Sharia Financing business activities by cooperatives no. 16/ Per/M.KUKM/ IX/2015 that: To expand business opportunities for the community to carry out productive activities, it is necessary to develop the implementation of savings and loan business activities and Sharia financing by cooperatives following applicable laws and principles Shari'ah, so that the community gets the maximum benefit and welfare.

Savings and Loans Cooperatives and Sharia Financing is a positive thing for people who have not been able to help business development. In this financial services field, cooperatives act as recipients and distributors of funds for their members. As recipients, cooperatives receive mandatory and voluntary deposits from their members. Meanwhile, as a distributor, cooperatives lend funds to those in need with several conditions or conditions that apply to the cooperative.

\section{BMT (Bait al-Mâl Wa al-Tamwîl)}

Bait al-Mâl Wa al-Tamwîl (BMT) is an institution consisting of two terms, namely Bait al-Mâl and Bait al-Tamwîl. According to Yuningrum (2012:25-26) Bait alMâl Wa al-Tamwîl (BMT) is a non-governmental group as a people's economic institution that seeks to develop productive businesses and investments with a profitsharing system to improve the economic quality of small entrepreneurs in poverty alleviation efforts.

The basic principles of the core product of Bait al-Mâl consist of: (1) Fundraising product, Bait al-Mâl receives and seeks funds in the form of zakat, infaq, and shadaqah, even though other than the source of the funds. (2) Fund distribution products sourced from Bait al-Mâl funds are specific, especially funds originating from zakat, because the means of distribution of these zakat funds have been explicitly stipulated in the Qur'an, namely to 8 (eight) ashnaf, including indigent, poor, amil, mu'alaf, fi sabilillah, gharimin, slaves, and travelers.

\section{MSME Financing (Micro, Small and Medium Enterprises).}

According to Muhammad (2000:119) the word financing is everything related to costs. Financing is an activity of BMT for its members to use and collect by its members. Financing can be divided into two based on the nature of its use (Antonio, 2001: 160), namely: (1) Productive financing, namely financing aimed at meeting production needs. (2) Consumptive financing, namely financing used to meet 
consumption needs. (3) Micro, Small and Medium Enterprises (MSMEs) is a term that refers to the type of business that has a net worth of a maximum of IDR 50,000,000 (fifty million rupiah) up to IDR 50,000,000,000 (fifty billion rupiah).

When viewed from the legal status, Muhammad and Khairandi (1991:54-97) state that MSME companies can be classified from various forms of companies in Indonesia, namely, as follows: (1) Legal Entity Company consisting of Limited Liability Company, cooperative and state-owned company. (2) Non-Legal Entity Companies consist of Firm Companies, Sole Proprietorships, and Limited Partnership Companies $(\mathrm{CV})$.

\section{Mudhârabah Contract}

Akad comes from the word العقد (al-'aqdu) which is a masdar form of 'aqada, ya'qidu, 'aqdan. In language, the contract is a bond between two things, both a real and a meaningful bond from one aspect or two aspects (Djamil, 2012: 4). In the world of sharia banking, the contract made has worldly and ukhrawi consequences because the contract made is based on Islamic law.

Mudhârabah comes from the word dharb which means to hit or rather the process of someone hitting his foot in the course of his business (Antonio, 2001:95). Technically, mudhârabah is business cooperation between two parties where the first party is the shahib al-mâl who provides all the capital (100\%), while the other party becomes the manager or mudharab. The fund owner only provides capital and is not allowed to interfere in the management of the business he finances.

Wajhu ad-dilâlah or the argument of Q.S Al-Muzammil 73:20 is that the word yadhribûn is the same as the root of the word mudhârabah, which means to make a business trip. "And those who walk on the earth seek some of Allah's bounty." (Q.S AlMuzammil, 73:20).

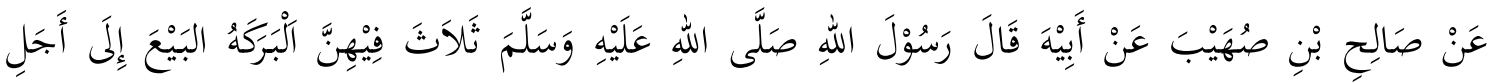

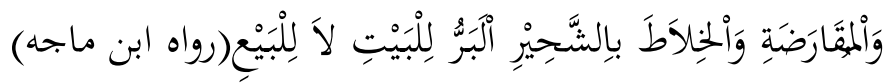

"From Salih bin Shuhaib that the Messenger of Allah said: three things in which there are blessings of buying and selling tough, muqaradhah (mudhârabah) and mixing wheat with flour for household purposes, not for sale." (HR. Ibn Majah No. 2280 , the book At-Tijarah).

The verse says that there is a connection with mudhârabah, namely that humans are sent to earth destined always to worship, strive to seek the grace and pleasure of Allah

\section{Methods}

The type of research used is qualitative research. According to Sujarweni (2015:21), qualitative research produces findings that cannot be achieved using statistical procedures or other means of quantification (measurement). The research 
method is descriptive. Meoleong (2000:3) says that descriptive research is a form of research that describes or describes existing phenomena, both natural phenomena and human engineering. In other words, descriptive research provides an overview and information based on facts obtained in the field carefully about certain individuals or groups about the circumstances that occurred.

Sources of data in this study are as follows: (1) Primary data, obtained through interviews with managers and employees of KSPPS-BMT eL-Taqwa Cidewa Ciamis regarding various matters in the implementation of the mudhârabah contract and interviews with several customers who received the financing regarding the development of the business being carried out. (2) Secondary data, as supporting data to determine the mudhârabah contract obtained by analyzing documents from KSPPSBMT eL-Taqwa Cidewa Ciamis, literature review, and journals about financing provided to Micro, Small, and Medium Enterprises.

The data collection techniques used are as follows: (1) Observation, this research can produce the necessary data and directly see the activities carried out at KSPPS-BMT eL-Taqwa. (2) Interviews were conducted with several employees and some Bait al-Mâl Wa al-Tamwl eL-Taqwa Sharia Savings and Loans Cooperative customers. (3) Study documents, obtained from KSPPS-BMT eL-Taqwa data related to the mudhârabah contract and also taken from books or literature that are relevant (according to) the issues to be discussed.

Data analysis can be carried out following the following stages: (1) Data collection. The data needed is collected as much as possible. The data collected is in words, pictures, and not numbers. Data derived from manuscripts, interviews, field notes, documents, and so on, are then described to provide clarity on reality or reality. (2) Data reduction. Is data obtained and written in the form of reports or detailed data. Reports are prepared based on the data obtained by reduction, summarized, selected the main points and focused on the important things. (3) Data Presentation. According to the main problem, the data obtained can be categorized, making it easier for researchers to see the pattern of relationships between one data and other data. (4) Conclusion and verification. The data that has been reduced, presented systematically will be concluded temporarily and verified. The technique used is triangulation of data sources, discussion methods and member checking.

\section{Results and Discussion}

The research was conducted at the Bait al-Mâl Wa al-Tamwîl EL-Taqwa Cidewa Ciamis Sharia Savings and Loans Cooperative. Located on Jl. KH. Zakaria RT. o3 RW.14 Dusun Cidewa, Adult Village, Cijeungjing District, Ciamis Regency.

Implementation of Mudhârabah Contracts in Financing Micro, Small and Medium Enterprises

In implementing the contract, KSPPS-BMT eL-Taqwa provides several types of contracts: the mudhârabah contract. This contract is usually used in financing products, namely working capital and investment financing. The type of business that gets financing from KSPPS-BMT eL-Taqwa is a form of productive financing for Micro, 
Small, and Medium Enterprises (MSMEs), such as what tempe entrepreneurs do. The minimum proposed financing is IDR 500,000, and the maximum financing is IDR 10,000,000. Customers who will apply for financing must meet the following requirements:

1) Member of KSPPS-BMT eL-Taqwa

2) Fill out the financing application form

3) Photocopy of KTP (Resident Identity Card)

4) Photocopy of KK (Family Card)

5) Letter of recommendation

6) Collateral in the form of securities

The KSPPS-BMT eL-Taqwa party determines the policy for the maximum length of financing to be carried out for ten months. KSPPS-BMT eL-Taqwa uses two categories in determining profit sharing. First, the profit sharing ratio (\%) for both parties is determined at the beginning of the contract at $2 \%$ before income is known that monthly installment payments are fixed. Second, the determination of the profitsharing ratio (\%) is determined at the beginning of the contract, but the installment payments are not fixed because it is adjusted to the customer's income.

The calculation of the ratio before income is known, namely financing of $\mathrm{Rp}$. $7,000,000,-$ with the provision for profit sharing as much as $2 \%$ for KSPPS-BMT eLTaqwa.

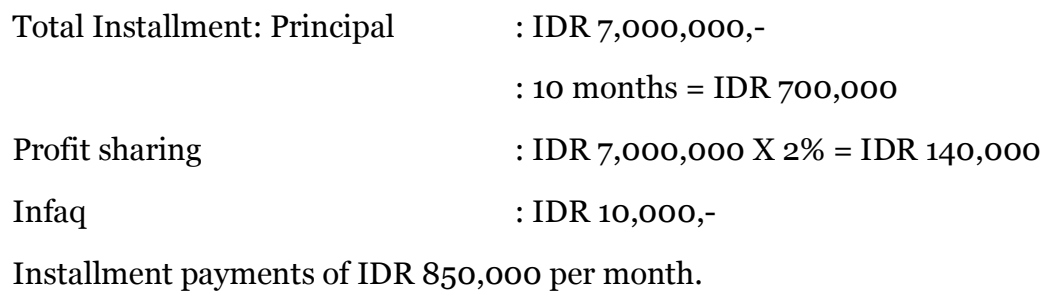

Installment payments of IDR 850,000 per month.

Profit sharing and installments that must be paid by customers every month do not change (fixed). The total obligations that must be paid by customers are Rp.

$8,500,000,-$ for 10 months. The calculation of the ratio before the income is known to borrow money of Rp. 10,000,000, - in 10 month installments. When the installment payment is made, the profit-sharing is calculated for 70:30 of the net profit generated by the customer. The profit earned in the first month is Rp. 80,000, - then the installments for that month are:

Principal installment

Profit sharing
: IDR 10,000,000

: 10 months = IDR 1,000,000 / month

: IDR 80,000 X $30 \%=$ IDR 24,000

So, in the first month, the customer must pay installments on KSPPS-BMT eLTaqwa of Rp.1,024,000,-. Likewise, for subsequent installments, it is adjusted to the profit earned by the customer and the obligation to pay installments every month is not fixed. The majority of customers who do mudhârabah financing want the profit sharing to be determined every month so that the agreement to determine the profit sharing is determined at the beginning of the financing contract before the income is known. This 
is because customers expect that the financing installments are not too difficult in calculating the profit sharing that must be paid.

The Role of Mudhârabah Contracts in the Development of Micro, Small and Medium Enterprises

The role of the mudhârabah contract provided by KSPPS-BMT eL-Taqwa is an effort to fulfill the wishes of Muslims and the surrounding community who want sharia financial services to manage and develop their economy, namely in the form of financing. People who run businesses are part of a society that has very good progress in economic development. However, capital is often the main obstacle for them to develop their business. The existence of KSPPS-BMT eL-Taqwa as an economic solution whose operations are in accordance with sharia principles, which can provide relatively affordable capital, easy terms, and easy, fast and precise procedures can be one of the solutions for providing loans capital to members in need.

The results of interviews from several sources can be concluded that the role of the mudhârabah contract for Micro, Small, and Medium Enterprises (MSMEs) in each additional capital given to customers is not all entrepreneurs feel the business development as expected. However, there are various kinds of business developments and obstacles experienced.

Some have experienced good business development, so that it is very helpful in the welfare of the economy of the surrounding community. In addition, customers who experience business constraints from the results and capital obtained are decreasing (decreasing business development), financing installment payments are hampered due to business competition factors.

Based on the results of this study, the implementation of the mudhârabah contract at KSPPS-BMT eL-Taqwa shows that in determining the profit sharing, the customer who carries out this financing contract the determination of the ratio is left to the KSPPS-BMT eL-Taqwa. The customer gives a reason because he does not expect an error in the calculation to cause an error in payment installments. From this statement, it can be said that there are still many customers who do not understand the implementation of the contract and the provisions that are clear in the DSN Fatwa (National Syari'ah Council) No. 07/DSN-MUI/VI/2000 concerning Mudhârabah (Qiradh) as follows: (A) Mudhârabah profit is the amount obtained as an excess of capital. The following profit conditions must be met. (b) b) The proportionate profit share for each party must be known and stated at the time the contract is concluded and must be in the form of a percentage (ratio) of the profit as agreed. Changes in the ratio must be based on agreement.

It is clear that the profit-sharing is determined at the time of the contract and the ratio is calculated from the profits that have been obtained. However, in operational practice (implementation) at KSPPS-BMT eL-Taqwa, it was found that there was a discrepancy between the theories or rules in Islam that had been set. However, this is done flexibly depending on the customer at hand, and if the profit-sharing is determined at the beginning of the contract or before profits are known, then this transaction is considered valid because it has been mutually agreed upon by both parties on a consensual basis. 
The mudhârabah financing agreement provided by KSPPS-BMT eL-Taqwa is one solution that can help businesses progress and has an important role in increasing income. Small communities around, especially entrepreneurs who lack funds, can easily get capital loans in the form of financing. As a result of this financing, MSMEs (Micro, Small and Medium Enterprises), which have developed, can provide job opportunities (job opportunities) for the surrounding community to help reduce unemployment and assist in the economic welfare of the community.

\section{Conclusion}

Based on the discussion of research on the implementation of mudhârabah contracts and the role of mudhârabah contracts for micro, small and medium enterprises (MSMEs) at KSPPS-BMT eL-Taqwa Cidewa Ciamis, several conclusions can be drawn, as follows: (1) The implementation of the mudhârabah contract at KSPPSBMT eL-Taqwa Cidewa Ciamis dominantly uses two categories in the mudhârabah contract service provided to customers (MSMEs), namely the distribution of the results of the ratio (\%) determined at the beginning of the contract before the income is known and the ratio (\%) for The actual result is determined when the mudharib income is known. This provision is flexible because the determination of the ratio (\%) depends on the request of the customer who submits it completely to the KSPPS-BMT eL-Taqwa Cidewa Ciamis. (2) The role of mudhârabah contracts for Micro, Small and Medium Enterprises (MSMEs) is of course various kinds of developments experienced by every entrepreneur. Judging from the customers who are developing well and can help improve the economic welfare of the surrounding community by creating jobs. Meanwhile, customers or entrepreneurs who experience a decline in their business development are due to experiencing more and more obstacles in business competition.

\section{REFERENCES}

Ananda, Fitria. (2011). Analisis Perkembangan Usaha Mikro Dan Kecil Setelah Memperoleh Pembiayaan Mudhârabah Dari Bmt At-Taqwa Halmahera Di Kota Semarang. Semarang. (t.p).

Antonio, M. Syafi'i. (2001). Bank Syariah dari Teori ke Praktik. Jakarta: Gema Insani. Chaniago, Arifinal. (1982). Perkoperasian Indonesia. Bandung: Angkasa.

Djamil, Fathurrahman. (2012). Penerapan Hukum Perjanjian dalam Transaksi di Lembaga Keuangan Syariah. Jakarta: Sinar Grafika.

Meoleong, Lexy J. (2000). Metodologi Penelitian Kualitatif. Bandung: PT Remaja Rosdakarya.

Muhammad, Abdul Kadir. (1991). Pengantar Hukum Perusahaan di Indonesia. Bandung: Citra Aditya Bakti.

Muhammad. (2000). Lembaga-Lembaga Keuangan Umat Kontemporer. Yogyakarta: UII Press.

Qordowi, Yusuf. (1997). Norma dan Etika Ekonomi Islam. Jakarta: Gema Insani Press. 
Sujarweni, V. Wiratna. (2015). Metodologi penelitian Ekonomi dan Bisnis. Yogyakarta: Pustaka Baru Press.

Yuningrum, Heny. (2012). Mengukur Kinerja Operasional BMT pada tahun 2010 dari segi Efiseiensi dengan Data Envelopment Analysis. Semarang: IAIN Walisongo. 
